Journal of Agricultural Sciences
(Tarim Bilimleri Dergisi)

\title{
The occurrence of Paraneognathus wangae (Fan \& Li) (Acari: Caligonellidae) and Raphignathus gracilis Rack (Acari: Raphignathidae) of stored products in Turkey
}

\author{
Sultan ÇOBANOĞLU ${ }^{a *} \mathbb{D}$, Ayhan ÖĞRETEN ${ }^{b} \mathbb{D}$, Eif SADE $^{\mathrm{C}} \mathbb{C}$ \\ ${ }^{a}$ Ankara University, Agricultural Faculty, Plant Protection Department, 06110, Dışkapı, Ankara, TURKEY

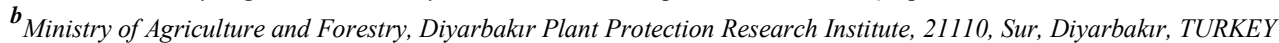 \\ ${ }^{c}$ Uludăg University, Institute of Science, Plant Protection Department, Görükle Campus, Bursa, TURKEY
}

\section{ARTICLE INFO}

Research Article

Corresponding Author: Sultan ÇOBANOĞLU, E-mail: scobanoglu@ankara.edu.tr

Received: 10 December 2019 / Revised: 18 December 2019 / Accepted: 22 December 2019 / Online: 31 May 2021

\section{ABSTRACT}

The occurrence of Paraneognathus wangae (Fan \& Li) (Acari: Caligonellidae) was reported for the first time in Turkey. This predatory species was found associated with stored wheat and collected from southeastern part of Anatolia. Measurements of female and male are provided along with their taxonomic characteristics and illustrations. This is also the first report on the occurrence of the genus Paraneognathus (Fan 2000) in Turkey. Raphignathus gracilis Rack (Acari: Raphignathidae) was also collected during this study as predatory species and rendered here.

Keywords: Mites, Caligonellidae, Paraneognathus, Mardin, Stored product, Turkey

(C) Ankara University, Faculty of Agriculture

\section{Introduction}

The Raphignathoidea Grandjean, 1944 (Acari: Prostigmata) includes 11 families: Barbutiidae, Caligonellidae, Camerobiidae, Cryptognathidae, Dasythyreidae, Eupalopsellidae, Homocaligidae, Mecognathidae, Raphignathidae, Stigmaeidae and Xenocaligonellididae, with 62 genera and 900 species (Fan \& Zhang 2005, Zhang et al. 2011). In Turkey, this superfamily is represented by 8 families, 25 genera and 192 species (Akyol 2017; Bingül et al. 2017; Doğan et al. 2019).

Caligonellids are small predators, that feed on small invertebrates. They mostly live on cracks of the tree, in litter and also associated with mosses, stored products, bird nests and soil (Summers \& Schlinger1955; Meyer \& Ueckermann 1989; Fan 2000). The position of the peritremal plate and shape of stylophore are important for the identification of the genus Paraneognathous (Ueckermann \& Khanjani 2003). Paraneognathus wangae (Fan \& Li) (Acari: Caligonellidae) described in firstly in Sinognathus Fan \& Li (1995) and collected from stored rice and the species later replaced in Paraneognathus (Fan 2000).

The genus Paraneognathus, can be identified as follows; idiosoma without eyes, with 11 pairs of dorsal setae, stylophore long and elongate, genital and anal opening are close to each other, peritreme confined to the edge of the stylophore.

In this paper, the genus Paraneognathus and the species $P$. wangae is reported for the first time from Turkey. $P$. wangae was found associated with stored products in Diyarbakır, Mardin and Muş provinces, which are located in the south-eastern part of Turkey. Besides, $R$. gracilis Rack was also collected in Calligonellidae as predatory species and included here.

\section{Material and Methods}

The mite samples were collected from stored products at Diyarbakır, Mardin and Muş provinces which are situated in the southeastern part of Turkey (Figure 1). The samples were taken randomly from different wheat storages with monthly intervals during 2013-2014. 


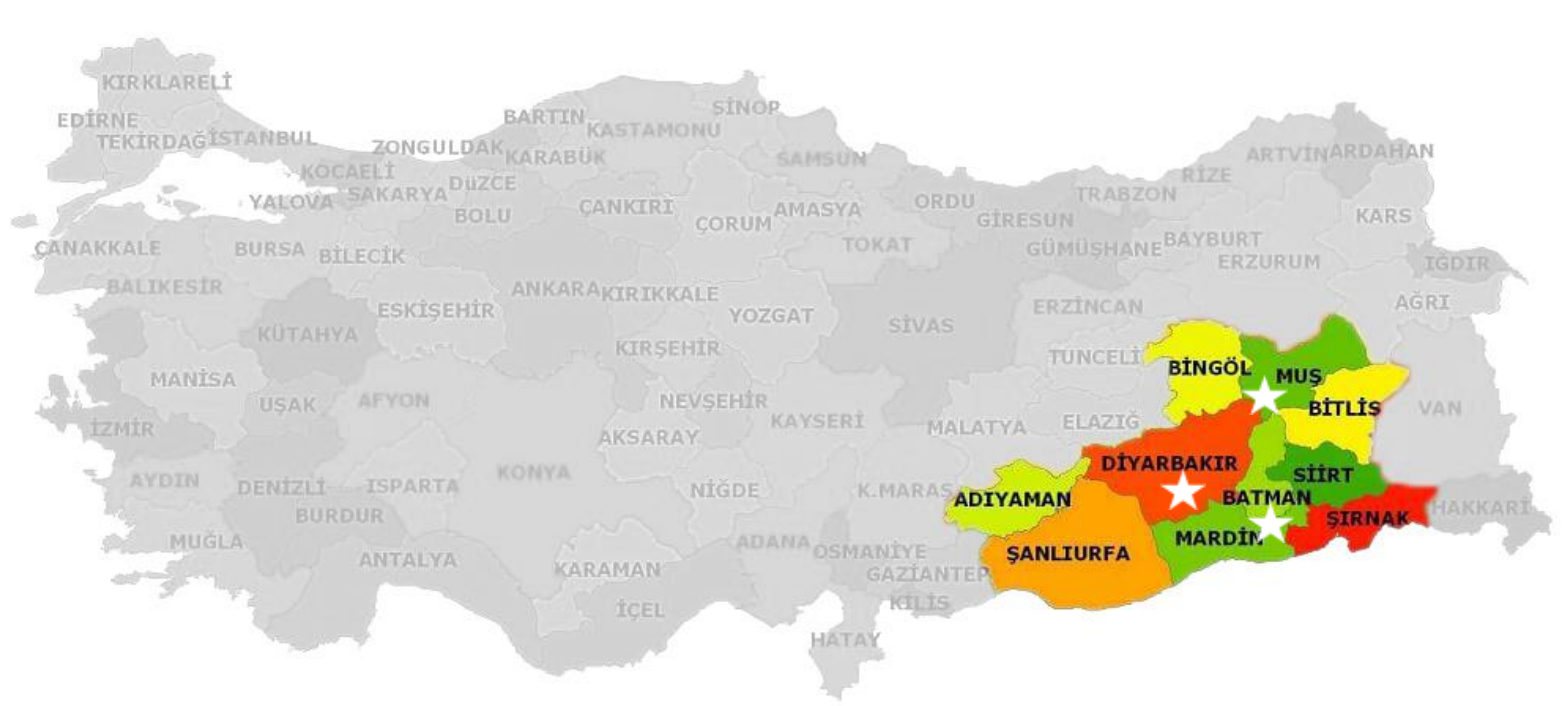

Figure 1- Mite samples collection locations

Wheat samples were taken with a split probe from the bulk, depending on the size of the stack in $4 \mathrm{~kg}$. All the samples were collected by the second author.

The mites were obtained by Berlese funnel and preserved in ethanol $70 \%$ for further studies. Mite samples were kept in lactic acid for clarification and mounted in Hoyer's medium with microscopic slides for identification. using a Leica compound microscope.

Measurements were obtained with a Leica ICC50 HD soft imaging system. Gnathosoma was measured from the base to tip of the chelicerae. Palpi; from palp trochanter to tip of tarsi; the length of the idiosoma, from the base of gnathosoma to posterior end. The width of the body, was measured at the level of $(c 2)$. The length of setae were considered from the base to their tips. The legs were measured from the base of the femur to the tip claw. Both setae and solenidia evaluated in the setal counts. All measurements are in micrometres $(\mu \mathrm{m})$.

The mite samples were deposited at Ankara University and, Diyarbakır Plant Protection Research Institute (Ministry of Agriculture and Forestry).

\section{Results and Discussion}

\section{Raphignathoidea \\ Caligonellidae Grandjean 1944 \\ Paraneognathus (Fan 2000) \\ Sinognathus (Fan \& Li 1995:326). \\ Paraneognathus wangae (Fan \& Li 1995)}

Diagnosis: Idiosoma does not include dorsal shield or eyes. Stylophore conical and elongated, peritremes (W) shapes and lying the edge to stylophore. Genital pore has $3(\mathrm{gl}-\mathrm{g} 3)$ pairs setae and with 4 pairs of aggenital setae.

\section{Paraneognathus wangae (Fan \& Li 1995)}

\section{Female (Figures 2-9)}

Oval shaped, body length 520, width 349, Palpus 223; gnathosoma (excluding palp) 153, width of gnathosoma 132.

\section{Dorsum (Figures 2-9)}

Dorsum soft and without shield and there are no eyes, integument striated simply. Prodorsum with four pairs setae; $v i, v e, s c i$ and sce. Dorsal setae barbed. Idiosomal setae measurements; vi 43; ve 44; sci 66; sce 58; c1 44; c2 70; d1 34; el 38; f1 43; h1 49; $h 2$ 66; ps1 24; length of between setae: vi-vi 37; vi-ve 40; vi-sci 61; vi-sce 43; sci-sci 90; sci-sce 74; sce-sce 222; sce-c2 72; c1-cl 91; c1-c2 120; cl-dl 46; c2-d1 49; c1-sce 105; d1-d1 106; d1-el 95; e1-el 104; el-fl 67;fl-fl 70;fl-h1 80; h1h1 27; h1-h2 39; h2-h2 95; h2-ps1 41; ps1-ps1 28. 
Gnathosoma (Figures 7, 9)

Chelicerae elongated with a very well developed stylophore plate which is conical at the base and surrounded by elongated peritremes $(\omega)$ shape including 9-10 septum of each side, at tip 3-4 septum sharply bent down. Subcapitular $(m, n)$ and adoral setae (orl, or 2 ); the length of setae: $m 50, n 47$; or 1 15, or 22.

Palpus: (from the femur to tip of tarsus) 223; palp tarsus has with a very well developed claw. Palpal chaetotaxy: femur and genua with 2 simple setae; tibia with 2 setae +1 well developed claw +1 accessory claw; tarsus with 1 tridentate eupathidium + 1 solenidion +5 setae (Figures. 9).

\section{Venter (Figure 4)}

Coxisternal area includes $1 a, 3 a$ and $4 a$; the length of setae: $1 a$ 53, 3a 47, 4a 46; with 4 pairs of agenital setae (ag $1-4)$, aggenital shields covered by striae; genital shields with 3 pairs setae ( $g 1-3)$ and pseudanal setae (psl-3); length of setae: ag $137, a g 2$ 25, ag3 27, ag4 23; g1 17, g2 19; g3 17,ps1 24,ps2 25 and ps3 19.

\section{Legs (Figures 5-8)}

Lengths; leg I 334; leg II 302; Leg III 284; Leg IV 404.

Legs chaetotaxy (setae and solenidia in brackets) $(\mathrm{I}-\mathrm{V})$ : coxae $2-2-2-2$; trochanters $1-1-2-1$; femora 6-6-3-2; genua $5(+1 \kappa)-5(+1 \kappa)-4-4$; tibiae $5(+2 \omega)-5(+1 \omega)-5(+1 \omega)-4(+1 \omega)$; $\operatorname{tarsi}: 15(+2 \omega)-12(+2 \omega)-9(+1 \omega)-9$.

TaI: $\omega$ I 11; $\omega$ II 18; Ta II $\omega I$ 9; $\omega$ II 14; TaIII $\omega 14$.
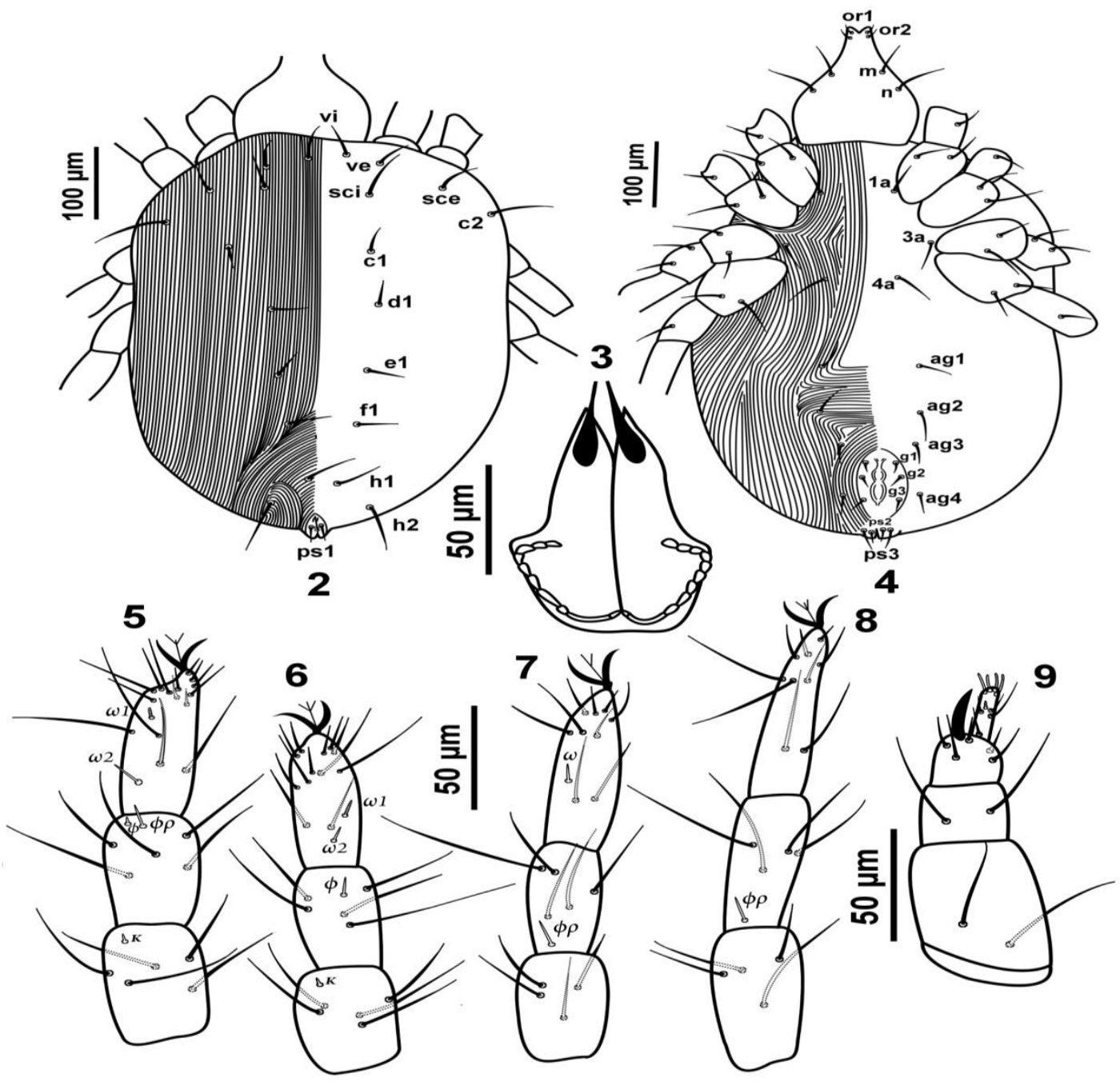

Figures 2- 9. Paraneognathus wangae (Female), 2. Dorsum, 3. Chelicera and Peritreme, 4. Venter, 5. Leg I, 6. Leg II, 7. Leg III, 8. Leg IV, 9. Palp. 
Male (Figures. 10-17)

Body length 433, width 220, Palpus 185; gnathosomal length (excluding palp) 137, width of gnathosoma 131.

Dorsum (Figure 10)

Setae measurements; vi 37; ve 38; sci 55; sce 46; cl 35; c2 53; d1 29; el 29; f1 44; h1 22; h2 68; psl 24; measurements of distance dorsal setae: vi-vi 39; ve-ve 108; vi-ve 42; ve-sci 37; sci-sci 91; sci-sce 47; sce-sce 170; sce-c2 63; c1-c1 64; c1-c2 97; c2-c2 222; cl-dl 76; dl-dl 73; d1-el 57; el-el 92; el-fl 25;fl-fl 92;fl-hl 31;fl-h2 79; hl-h2 89; hl-hl 78; h1-h2 75; $h 2-h 289$.

Gnathosoma (Figure 11)

Chelicerae with a conical stylophore and surrounded by elongated peritremes $(\omega)$ shapes including 9-10 septum of each side. Subcapitular setae $(m, n)$ and adoral setae (or1, or 2$)$; subcapitular setae: $m$ 33, $n 43$.

Palpus (from the base of femur to tip of tarsus) 185; Palp tarsus have with a very well developed claw. Palpal tarsus: 1 tridentate eupathidium +1 solenidion +5 simple setae; tibia: 2 setae +1 developed claw +1 accessory claw; genua: 2 and femur include 2 tiny setae (Figure 15).

Venter (Figure 12)

Coxisternal area includes $(1 a, 3 a$ and $4 a)$; the length of these setae: 34,29 and 30 .

Aggenital setae 4 pairs (agl-4), anogenital shields with 6 pair 1 setae ( $g 1-6)$ and pseudanal setae (psl-3); lengths: ag1 37, ag240, ag3 60, ag4 31; ps1-3 26; ps3 26

Legs (Figures.13-17)

Lengths; leg I 334, leg II 302; Leg III 332; Leg IV 404;

Male leg segments setal formula (setae and solenidia in parantheses) $(\mathrm{I}-\mathrm{V})$ :

Femur one has sensory setae of tarsi I and II which are subequal in length.

The setal formula of leg segments as (I-V): coxae 2-2-2-2; trochanters 1-1-2-1; femora 6-6-3-2; Femora III with a flangelike apopyhse; genua $5(+1 \kappa)-5(+1 \kappa)-4-4$; tibiae $5(+2 \omega)-5(+1 \omega)-5(+1 \omega)-4(+1 \omega)$; $\operatorname{tarsi}: 15(+2 \omega)-12(+2 \omega)-9(+1 \omega)-9$.

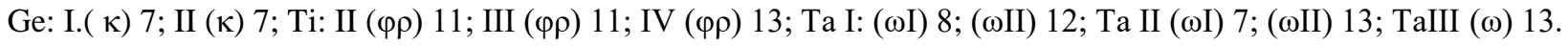

Material Examined: $7 q q$ and $6 \lesssim \widehat{\jmath}$ from whole wheat Mardin (37120950N:40362365E), 06-06-2014, and $1 q$ from stored wheat, Muş (Kayapınar) (38425333N:41373057E), 13-06-2014.

Distribution: China, Iran, Brazil and Turkey (with this study) (Ardeshir et al. 2014; Fan \& Li 1995; Silva et al. 2015).

Remarks. The Turkish specimens resemble the original description of $P$. wangae in all aspects. $P$. wangae is very close to Paraneognathus summersi, which has tarsi I with 16 setae and genu I with 7 setae while $P$. wangae has tarsi I 17 and genu I with 6 setae respectively. This species is also very close to Paraneognathus oblongus, which has a very strong spine-like sensory setae of tarsus I which is longer than tarsus II while it has subequal length in $P$. wangae. For coxal chaetotaxy, it was mentioned that 2-2-2-2 in Iranian specimen (Fan \& Li 1995; Ardeshir et al. 2014). Our specimens have the same coxal chaetotaxy as Iranian specimen have.

\section{Raphignathidae}

Raphignathus Dugés

Raphignathus gracilis (Rack 1962)

Acheles gracilis Rack 1962: 281.

Raphignathus gracilis (Rack), (Koç \& Ayyıldız 1996: 210; Doğan 2003: 145. Doğan 2007)

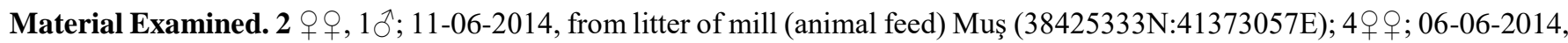
Diyarbakır (Mill) wheat (37565066N:40140041E); 2q, 13-06-2014 from stored wheat, Diyarbakır (Kayapınar) (37544774N:40051301E), Turkey

Distribution: Algeria, China, Egypt; former U.S.S.R., Germany, Israel, Japan, New Zealand; Turkey; U.S.A., (Meyer \& Ueckermann 1989; Li et al. 1992; Hu et al 1995; Fan \& Yin 2000; Zaher \& Gomaa 1979; Wainstein \& Kuznetsov 1978; Rack 
1962; Gerson 1968; Ehara 1980; Fan \& Zhang 2005; Charlet \& McMurtry 1977; Koç \& Ayyildiz 1996; Doğan 2007; Yeşilayer \& Çobanoğlu 2013).

Remarks; This species was collected previously in Artvin, Denizli, Erzurum, Erzincan and Istanbul. Its habitats are; litter and soil under Alnus sp. (Betulaceae), Castanea sp. (Fagaceae), Euonymus fortunei (Turcz.) (Apocynaceae); Pistacia sp. (Anacardiaceae), Quercus sp. (Quercaceae), Rhododendron sp. (Ericaceae), Tamarix sp. (Tamaricaceae), Ulmus sp. (Ulmaceae) and Vitis sp. (Vitaceae); grassy soil from olive grove; moss on soil and stone (Doğan 2007; Yeşilayer \& Çobanoğlu 2013).

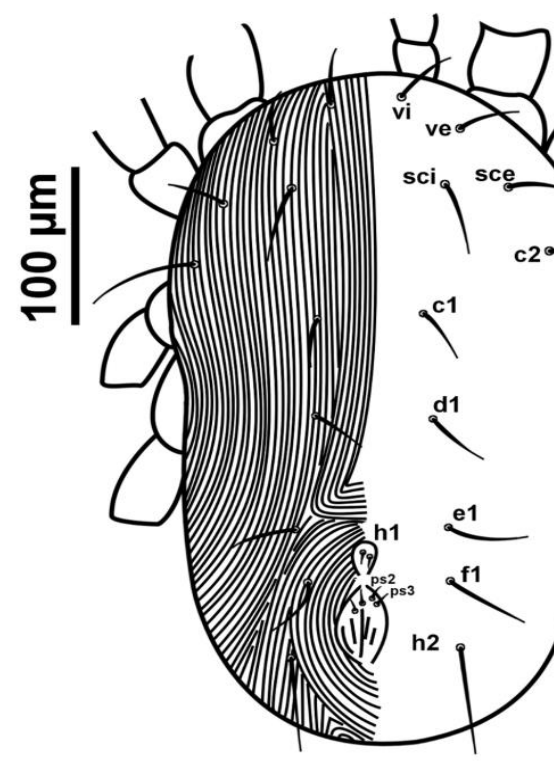

10
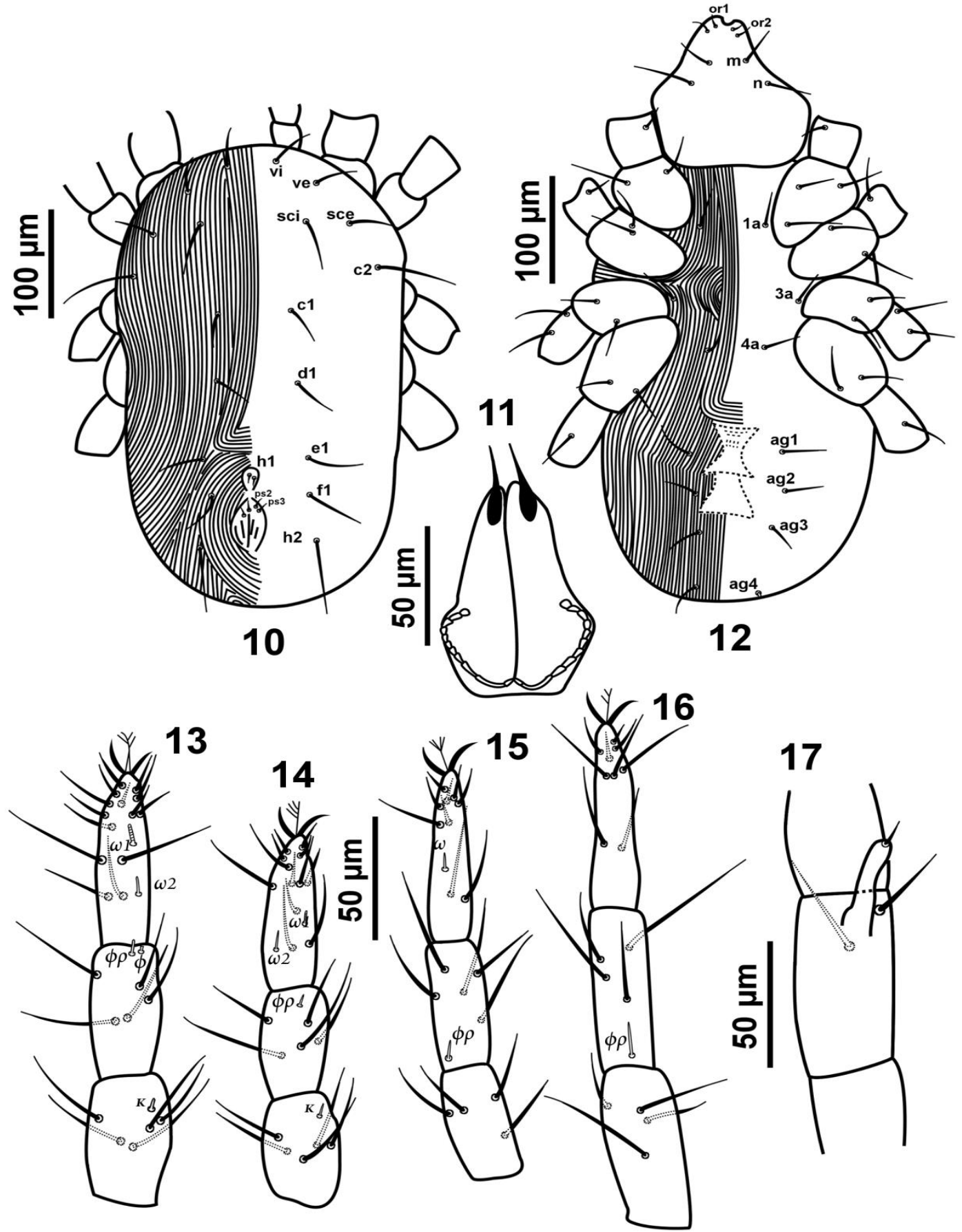

Figures 10-17. Paraneognathus wangae (Male), 10. Dorsum, 11. Chelicera and Peritreme, 12. Venter, 13. Leg I, 14. Leg II, 15. Leg III, 16. Leg IV, 17. Femur III

\section{Acknowledgements}

This article is part of the PhD. thesis of the second author (A. Öğreten). The authors would like to thank Prof. Edward A. Ueckermann (Potchefstroom, 2520, South Africa) for confirmation of the species. The authors wish to thank Sreerama Kumar Prakya Principal Scientist (Plant Pathology, Bengaluru - India) early reading of the manuscript and her comments, 


\section{References}

Akyol M (2017). Fauna of Coastal Aegean Rafignatoid Mites (Acari: Prostigmata: Raphignathoidea). Plant Protection Bulletin 57(2): 205-229 https://doi.org/10.16955/bitkorb.305402

Ardeshir F, Bagherş M \& Saeej S P (2014). Redescription of male and female of Paraneognathus wangae (Fan \& Li) (Acari: Caligonellidae) with a key to all known species of the genus Paraneognathus. Persian Journal Acarology 3(2): 145-151 https://doi.org/10.22073/pja.v3i2.17132

Bingül M, Doğan S \& Dilkaraoğlu S (2017). Contributions to the knowledge of the mite genus Stigmaeus Koch (Acari: Stigmaeidae) of Turkey. European Journal of Taxonomy 307: 1-16 https://doi.org/10.5852/ejt.2017.307

Charlet I D \& McMurtry J A (1977). Systematics and bionomics of predaceous and phytophagous mites associated with pine foliage in California. Hilgardia 45: 173-210 DOI:10.3733/hilg.v45n07p173

Doğan S (2003) Descriptions of three new species and two new records of Raphignathus Dugés (Acari: Raphignathidae) from Turkey. Archives des Sciences 56: 143-153

Doğan S (2007). Checklist of raphignathoid mites (Acari: Raphignathoidea) of Turkey. Zootaxa 1454: 1-26 https://doi.org/10.11646/zootaxa.1454.1.1

Doğan S, Doğan S \& Erman O (2019). Mites of Raphignathus Dugés (Acari: Raphignathidae) from Harşit Valley (Turkey), with taxonomic notes on other members of the genus. Plant Protection Bulletin 59 (1): 25-36 https://doi.org/10.16955/bitkorb.419431

Ehara S (1980). Illustrations of the mites and ticks of Japan. Zenkoku Noson Kyoiku Kyokai pp. 562

Fan Q H (2000). A phylogenetic analysis of the family Caligonellidae (Acari: Prostigmata) with description of two new species. Acta Entomologica Snica 43: 421-428

Fan Q H \& Li L S (1995). A new genus and a new species of Caligonellidae associated with food from China. Acta Zootaxonomica Sinica 20(30): 323-327

Fan Q H \& Yin X M (2000). The genus Raphignathus (Acari: Raphignathidae) from China. Systematic and Applied Acarology 5: 83-98

Fan Q H \& Zhang Z Q (2005). Raphignathoidea (Acari: Prostigmata). Fauna of New Zealand 52: 1-400

Gerson U (1968). Some raphignathoid mites from Israel. Journal of Natural History 2: $429-437$ https://doi.org/10.1080/00222936800770411

Grandjean F (1944). Observations sur les acariens de la famille des Stigmaeidae. Archives des Sciences Physiques et Naturelles 26: $103-131$

Hu C Y, Jing Z Q \& Liang L R (1995). Two new species and one new record of the genus Raphignathus Duges (Acari: Raphignathidae). Journal of Suzhou Railway Teachers College 12(3): 21-26

Koç K \& Ayyıldız N (1996). Türkiye faunası için yeni iki Raphignathus Dugès (Acari, Prostigmata, Raphignathidae) türü. Turkish Journal of Zoology 20: 209-214

Meyer M K P \& Ueckermann E A (1989). African Raphignathoidea. Entomology Memoir Department of Agriculture and Water Supply, Republic of South Africa 74: 1-58 https://doi.org/10.7931/J2/FNZ.52

Rack G (1962). Milben aus Taubennestern mit Beschreibung einer neren Art, Acheles gracilis (Acarina, Raphignathidae). Zoologischer Anzeiger 168(7-10): 275-292

Ueckermann E A \& Khanjani M (2003). Iranian Caligonellidae (Acari: Prostigmata), with description of two new species and re description of Molothrognathus fulgidus Summers and Schlinger, with a key to genera and species. Acarologia 43: 291-298

Silva D E, da Silva I C O, Horn T B \& Ferla N J (2015). First record of Paraneognathus wangae (Acari: Caligonellidae) in Brazil. Symposio Brasileiro de Acarologia, Acarologia integrative ISBN 97885 66836-08-08

Summers F M \& Schlinger E I (1955). Mites of family Caligonellidae (Acarina). Hilgardia 23: 539-561 DOI:10.3733/hilg.v23n12p539

Wainstein B A \& Kuznetsov N N (1978). Family Raphignathidae. In: Gilyarov, M. S. (ed.) Identification Key of Soil Inhabiting Mites. Trombidiformes. Nauka,Moscow pp. 149-150

Yeşilayer A \& Çobanoğlu S (2013). Determination of raphignathoid mites (Acari: Prostigmata: Raphignathoidea) ornamental plants of Istanbul (Turkey). Turkish Journal of Entomology 37: 93-103

Zaher M A \& Gomaa E A (1979). Three new species of the genus Raphignathus in Egypt (Prostigmata: Raphignathidae). Acarologia 21(2): 187-203

Zhang Z-Q, Fan Q-H, Pesic V, Smit H, Bochkov AV, Khaustov AA, Baker A, Wohltmann A, Wen T-H, Amrine JW, Beron P, Lin J, Gabrys G \& Husband R (2011). Order Trombidiformes Reuter,1909. In: Zhang Z.-Q. (ed.) Animal biodiversity: an outline of higher-level classification and survey of taxonomic richness. Zootaxa 3148: 129-138 https://doi.org/10.11646/zootaxa.3148.1.24

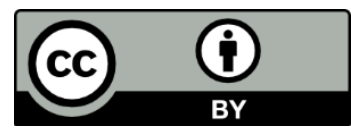

(C) 2021 by the authors. Licensee Ankara University, Faculty of Agriculture, Ankara, Turkey. This article is an open access article distributed under the terms and conditions of the Creative Commons Attribution (CC BY) license (http://creativecommons.org/licenses/by/4.0/). 